\title{
Public Relations Dalam Membina Hubungan Dengan Media
}

\author{
${ }^{1}$ Diajeng Herika, ${ }^{2}$ Poppy Ruliana \\ ${ }^{1}$ Konsentrasi Public Relations STIKOM InterStudi, ${ }^{2}$ LPPM STIKOM InterStudi
}

\begin{abstract}
The main purpose of this paper is to know and examine the importance of the role of public relations in developing media relations, both traditional media and social media used to build the image or reputation of the company. Media relations involves collaborating with the media in the form of printed media, electronic media and online media to inform the mission, policies and practices of the organization in a positive, consistent and reliable way. Typically, this means coordinating directly with the people responsible for producing news and features in the mass media. 'The purpose of media relations is to maximize positive coverage in the mass media
\end{abstract}

\section{Pendahuluan}

Awalnya, hubungan media didasarkan pada hubungan dengan reporter yang dibangun dalam jangka waktu yang panjang. Profesional humas membangun arsip informasi yang besar tentang wartawan selama pertemuan. Saat ini, hubungan media adalah proses yang lebih ilmiah berdasarkan analisis karya sebelumnya reporter, sudut pandang mereka mengenai topik tertentu dan interaksi mereka sebelumnya. Perusahaan mencoba mengelola hubungan dengan media baik untuk publikasi tradisional maupun saluran televisi serta media sosial (media digital) dengan membuat berita, yang dikenal sebagai pendekatan proaktif. Korporasi juga dapat mendistribusikan siaran pers atau menanggapi panggilan saat reporter mengembangkan cerita, yang dikenal sebagai pendekatan reaktif.

Banyak orang menggunakan

istilah hubungan masyarakat dan hubungan media secara bergantian; Namun, melakukan hal itu tidak benar. Hubungan media mengacu pada hubungan yang dikembangkan perusahaan atau organisasi dengan para jurnalis, sementara hubungan masyarakat memperluas hubungan tersebut di luar media kepada masyarakat umum. Ada kemungkinan komunikasi antara media dan organisasi diprakarsai oleh kedua belah pihak, namun berurusan dengan media menghadirkan tantangan unik karena media berita tidak dapat dikendalikan mereka memiliki kontrol penuh atas apakah cerita yang diajukan kepada mereka menarik bagi mereka. penonton. Karena kenyataan ini, hubungan yang berkelanjutan antara organisasi dan media berita sangat penting. Salah satu cara untuk memastikan hubungan kerja yang positif dengan personil media adalah menjadi sangat akrab dengan "ketukan" dan bidang minat mereka. Hubungan media dan praktisi hubungan masyarakat harus membaca sebanyak mungkin majalah, jurnal, surat kabar, dan blog sebanyak mungkin, karena berhubungan dengan praktik seseorang.

Hubungan media dapat digambarkan sebagai interaksi perusahaan dengan editor, reporter dan jurnalis. Media bisa berupa surat kabar, radio, televisi dan internet. Tujuannya adalah untuk mengkomunikasikan pesan, cerita atau informasi yang layak diberitakan kepada klien menggunakan media yang sesuai. Perusahaan mungkin hanya memerlukan satu orang untuk bekerja dengan media atau memilih untuk menyewa tim tergantung pada jumlah informasi yang harus dikendalikan. Hal ini bisa dilakukan 
secara internal atau eksternal sehingga bisa menyelesaikan pekerjaan. Spesialis hubungan media biasanya terhubung dengan dunia media setiap hari. Para profesional ini bekerja untuk mengembangkan dan merancang rencana media yang bisa menjadi cetak biru untuk apa yang diharapkan perusahaan capai di tingkat lokal, nasional atau internasional. Strategi bisnis dirancang untuk mengelola dan menciptakan persepsi positif terhadap perusahaan.

Sebagai spesialis hubungan media yang efektif, sangat penting untuk bekerja sama dan tidak melawan media. Mengembangkan hubungan yang kuat dengan para jurnalis, blogger, dan penulis konten yang mungkin ingin mendengar apa yang harus Anda katakan, dapat memberi klien Anda akses tak ternilai kepada publik. Sementara garis tak terlihat ditarik antara hubungan masyarakat dan hubungan media, para profesional di kedua bidang harus menjadi ahli dalam komunikasi massa untuk menjadi sukses. Informasi tren harus diantisipasi dan dipahami dengan baik sebelumnya. Dan itu harus cepat diakses.

Hubungan Media melibatkan kerja sama dengan media untuk menginformasikan misi, kebijakan, dan praktik organisasi secara positif, konsisten dan dapat dipercaya. Biasanya, ini berarti berkoordinasi secara langsung dengan orang-orang yang bertanggung jawab untuk memproduksi berita dan fitur di media massa. ' Tujuan dari hubungan media adalah memaksimalkan liputan positif di media massa tanpa membayarnya secara langsung melalui periklanan.

\section{Metode Penulisan}

Tujuan utama penulisan makalah ini adalah untuk mengetahui dan menelaah pentingnya media relations yang dilaksanakan oleh seorang public relations dalam suatu Organisasi. Metode penulisan bersifat studi pustaka. Informasi didapatkan dari berbagai literatur dan disusun berdasarkan hasil studi dari informasi yang diperoleh dari berbagai literature dan online. Penulisan diupayakan saling terkait antar satu sama lain dan sesuai dengan topik yang dibahas. Beberapa jenis referensi utama yang digunakan adalah buku komunikasi, jurnal imiah edisi cetak maupun edisi online, dan artikel ilmiah yang bersumber dari internet. Jenis data yang diperoleh variatif, bersifat kualitatif maupun kuantitatif.

\section{Pembahasan}

\section{Konsep Public Relations (PR)}

Public relations (PR)
memainkan peran penting dalam membangun hubungan media terutama dalam membentuk identitas, citra reputasi perusahaan atau organisasi di era digital saat ini merupakan tantangan yang harus dihadapi. Betapa tidak, arus informasi tersaji dengan cepat. Orangorang bisa mendapatkan berita terkini tanpa harus menyalakan layar tv. Hanya dengan mengakses media sosial melalui gadget masing-masing berita aktual dapat diakses dengan cepat. Public Relations professional haruslah sadar betul bahwa media memiliki peran penting dalam kegiatan publikasi. Sehingga penting bagi Public Relations untuk menjalih hubungan dengan media atau yang selanjutnya disebut dengan Media Relations. Media relations merupakan aktivitas yang dilakukan oleh seorang Public Relations yang berhubungan dengan media massa, dalam hal ini adalah kegiatan publikasi perusahaan. Media relations penting dilakukan bagi seorang Public Relations 
karena tujuan utamanya adalah untuk membentuk reputasi perusahaan

Public Relations tindakan menghubungkan dan berkomunikasi melalui berbagai hubungan yang mungkin dibentuk oleh sebuah bisnis atau organisasi dengan publik. Berbagai kepentingan publik ini mencakup karyawan, pelanggan, industri, entitas pemerintah, investor, badan amal, pemasok dan media.. Public Relations Society of America menyatakan bahwa, ", "Public relations is a strategic communication process that builds mutually beneficial relationships between organizations and their communities." PR mempertimbangkan gambaran yang lebih besar tentang bagaimana sebuah organisasi berhubungan dan dirasakan oleh masyarakat luas. Strategi public relations yang baik tidak hanya dapat membantu perusahaan memahami pelanggannya dan memberikan solusi yang berarti, namun melacak hasilnya dan sering meramalkan hasil untuk keadaan masa depan. PR dapat mempengaruhi perilaku masyarakat terkadang bahkan lebih dari sekedar iklan. Di samping itu penting untuk diketahui jenis-jenis naskah untuk dikirim/dimuat di media massa antara lain:

1. Press Release - informasi tertulis atau naskah berita.

2. Feature -karangan khas.

3. Artikel-naskah opini.

4. Advertorial (Pariwara)-iklan berupa berita, feature, atau artikel.

5. Surat Pembaca -misalnya memberikan Hak Jawab.

Profesional PR sering bekerja sama dengan manajemen senior sebuah organisasi untuk berhubungan langsung dengan kejadian perusahaan internal dan eksternal yang kritis. Kedua media tradisional dan tentunya sekarang internet dimanfaatkan untuk mengkomunikasikan pesan yang sesuai. Kotak peralatan profesional PR mencakup kemampuan untuk meneliti, menulis dan berbicara.

\section{Model Media Digital PR dalam Media Relation}

Gambar di bawah in menunjukkan penggunaan empat model PR Grunig dan Hunt yang diaplikasikan dalam kegiatan PR dengan menggunakan media digital saat ini, Grunig (2009) optimis bahwa "Although many practitioners have simply transferred their media relations skills and techniques to digital media, the new fascination with social media promises to have positive consequences for the public relations profession."'Media digital ini menurut keduanya dapat digunakan untuk:

- Two-way interactive and dialogical communication with stakeholders (media organisations, employees, financial institutions, regulators etc).

- Environmental scanning research and identification of problems, publics, and issues (media monitoring).

- Stakeholder and publics segmentation.

- Issues and crises communication programmes.

- Measuring the type and quality of relationships developed with publics, their cognitions, attitudes and behaviours. .Selwyn Jerry Bostonselwynbostonpr.blogspot.co

$\underline{m}$

Selanjutnya Grunig menggambarkan bagaimana penggunaan empat model perkembangan PR dalam gambar di bawah ini: 


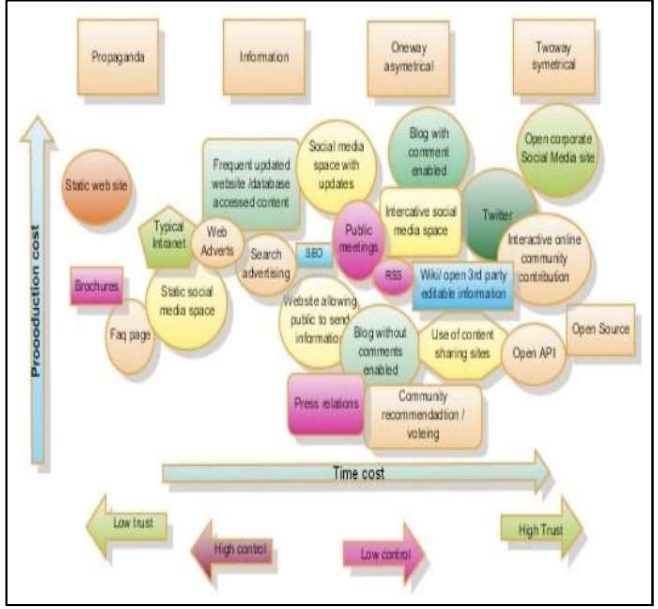

Gambar. 1: Penggunaaan Empat Model Perkembangan PR.Sumber : Grunig dalam Selwyn Jerry Boston selwynbostonpr.blogspot.com

Berkaitan dengan gambar satu di atas, Phillips (2009) menunjukkan media digital masih digunakan secara luas untuk program komunikasi yang satu arah dan asimetris. Namun, banyak organisasi sekarang sedang mengembangkan dua arah, interaktif, dan program komunikasi dialogis melalui media digital, terutama menggunakan blog dan mikroblog seperti Twitter. Rebecca Harris (2009) dari General Motors dan Brandy King (2009) dari Southwest Airlines dijelaskan dua program tersebut pada 2009 Summit on Measurement of the $U$. $S$. Institute for Public Relations.. Southwest Airlines memiliki blog untuk karyawan dan pelanggan disebut Nuts About Southwest

(http://www.blogsouthwest.com).

Peralatan Media Digital dalam Kegiatan Public Relations

Media digital dapat dijadikan alat penting dalam pelaksanaan kegiatan PR dan juga membina hubungan media, karena sebagaimana dikemukakan Grunig bahwa media digital sangat efektif dalam melaksanakan perencanaan program kegiatan $P R$ dalam suatu perusahaan, seperti berikut

\section{Communication programmes}

Media digital digunakan secara luas untuk hubungan media, hubungan pelanggan, hubungan keuangan, hubungan masyarakat, hubungan anggota untuk non-profit, hubungan donor, hubungan alumni untuk perguruan tinggi dan universitas, urusan publik dan hubungan masyarakat politik, dan banyak program lain yang dirancang untuk menumbuhkan hubungan dengan publik.

\section{Pemindaian Lingkungan (Environmental Scanning)}

Media digital yang ideal untuk penelitian scanning lingkungan, dan ada banyak alat yang tersedia untuk memindai dunia maya untuk masalah, publik, dan isu-isu. Alat-alat ini dapat sebagai mudah dilakukan sebagai menyiapkan lansiran Google menggunakan nama organisasi sebagai kata kunci, dengan memasukkan kata kunci yang menggambarkan potensi masalah dan isu-isu yang berhubungan dengan organisasi, atau memasuki kata kunci yang terkait dengan keputusan atau kebiasaan yang Tim manajemen mungkin merenungkan tetapi belum diimplementasikan. Alat pemantauan media sekarang tersedia secara luas untuk digunakan di dunia maya. Grunig mengemukakan bahwa pemantauan media sebenarnya jauh lebih berharga bila digunakan untuk media digital daripada media tradisional. Pemantauan media digital dapat digunakan untuk pemindaian lingkungan sedangkan pemantauan media tradisional biasanya dilakukan kebanyakan untuk mengevaluasi program hubungan media. Meskipun masih banyak perdebatan mengenai apakah media digital harus dipantau menggunakan mesin otomatis coding atau pengkodean manusia (Penelitian, 2009), para peneliti 
memperdebatkan masalah ini setuju bahwa kedua metode dapat digunakan dalam situasi yang berbeda dan bahwa keduanya memiliki kelebihan yang unik.

\section{Segmentasi Stakeholders Dan Publik (Segmenting Stakeholders And Publics)}

Meskipun sebagian besar penulis tentang hubungan masyarakat cenderung menggunakan istilah 'stakeholder' dan 'publik' secara bergantian, saya membedakan antara keduanya. Grunig menggunakan istilah pemangku kepentingan untuk menentukan kelompok luas orang dengan saham sejenis dalam organisasi, seperti karyawan, pelanggan, atau anggota masyarakat. Stakeholder dapat didefinisikan sebagai orang yang memiliki risiko yang sama yang dihasilkan dari hubungan dengan sebuah organisasi (Post, Preston, \& Sachs, 2002). Tidak setiap anggota dari kelompok pemangku kepentingan adalah anggota masyarakat yang sama, namun; seperti Gambar diatas mengilustrasikan, beberapa jenis publik dapat ditemukan dalam setiap kategori pemangku kepentingan. Publik ini dapat berkisar dari aktivis untuk aktif, pasif, dan non-publik.

Phillips dan Young (2009) telah mencatat, penting untuk segmen stakeholder dan publik untuk memahami hubungan mereka yang berbeda dengan organisasi dan untuk dapat berkomunikasi dengan mereka tentang masalah dan kepentingan menggunakan media baru mereka. Segmen stakeholder mengidentifikasi dampak konsekuensi atau konsekuensi potensial keputusan manajemen pada kelompok-kelompok seperti karyawan, pelanggan, atau pemegang saham. Kemudian lebih lanjut segmen dari kelompok pemangku kepentingan ini menggunakan teori situasional dari publik (misalnya, Grunig, 1997; Kim \&
Grunig, di tekan). Ini segmen teori publik menggunakan konsep pengakuan masalah, pengakuan kendala, dan pengakuan keterlibatan. Phillips dan Young (2009) juga menyarankan segmentasi publik oleh nilai-nilai dan konsep. Selain nilai-nilai dan konsep, saya akan menambahkan ideologi sebagai konsep segmentasi. Namun, saya akan mengintegrasikan konsepkonsep ini ke dalam teori situasional dari publik karena saya percaya nilainilai, konsep, dan ideologi mempengaruhi masalah orang mengenali dan bagaimana mereka mendefinisikan mereka.Saya percaya bahwa peneliti PR bisa stakeholder segmen dan publik menggunakan konten media digital sebagai database. Meskipun saya belum melakukannya, saya percaya bahwa teknik analisis isi dapat digunakan dengan bahan online untuk mengidentifikasi dan konsep kode seperti masalah, kendala, dan jenis keterlibatan, menggunakan teori situasional, serta nilai-nilai, konsep, dan ideologi . Setelah diidentifikasi, masalah yang diakui oleh publik ini dapat dikomunikasikan kepada manajemen karena membuat keputusan; dan kategori publik berasal dari konsepkonsep ini dapat digunakan sebagai penelitian formatif untuk merencanakan program komunikasi.

\section{Mengantisipasi \\ Dan Berurusan Dengan Isu-Isu Dan Krisis}

sebagian besar masalah hasil dari tindakan publik (publik membuat isu dari masalah) dan bahwa sebagian besar, tapi tidak semua, krisis hasil dari tanggapan manajemen miskin untuk masalah. Dengan demikian, analisis media online dapat terus berlanjut setelah segmentasi pemangku kepentingan dan publik untuk mencari dan mengkategorikan isu publik akan menaikkan dan krisis yang mungkin timbul dari masalah ini. Media digital 
seperti website dan blog juga dapat digunakan untuk isu dan program komunikasi krisis (Coombs, 2008). General Motors, misalnya, digunakan blog dan halaman web beberapa saat yang kebangkrutan krisis 2009 (Harris, 2009). Organisasi juga sedang mengembangkan situs web gelap yang siap untuk pergi ketika krisis terjadi, seperti bencana alam atau kecelakaan, yang bisa diantisipasi dalam industri atau lingkungan mereka

5. Mengukur Hubungan Dan Reputasi (Measuring Relationships And Reputation) Hubungan media dan reputasi. Organisasi yang segmen pemangku kepentingan dan publik mereka, mengantisipasi dan menangani masalah dan krisis, dan secara aktif berkomunikasi dengan publik pada semua tahap proses, harus lebih mungkin untuk mengembangkan hubungan dengan publik mereka yang memungkinkan untuk mencapai tujuan organisasi, mengembangkan positif reputasi, dan mengurangi konsekuensi dari hubungan buruk tentang pelaksanaan keputusan manajemen. Seperti fase lain dari proses ini, saya percaya adalah mungkin untuk menggunakan dunia maya sebagai database untuk mengukur jenis dan kualitas hubungan dikembangkan dengan publik menggunakan konsep kepercayaan, kebersamaan kontrol, kepuasan, dan komitmen yang dikembangkan oleh Grunig dan Huang ( 2000), Grunig (2002), dan Hon dan Grunig (1999). Mengukur hubungan dengan cara ini akan membutuhkan skema analitik konten yang mencerminkan konsep hubungan. Selain mengukur hubungan dari konten online secara langsung, penelitian survei tambahan dapat dilakukan untuk mengevaluasi hasil program komunikasi dilaksanakan melalui media sosial
(Paine, 2007a). Akhirnya, reputasi dapat diukur dengan menggunakan Bromley (1993) dan Grunig dan Hung (2002) definisi reputasi sebagai apa yang orang pikirkan dan katakan tentang Anda. Hal ini dapat dilakukan dengan mengukur tema yang mencerminkan perilaku yang paling umum dan atribut dari suatu organisasi yang dibahas di dunia maya. Sebagai Phillips dan Young (2009) mengatakan, "reputasi Anda ... akan semakin tergantung pada apa yang muncul ketika Anda Googled" (hal. 157).

6. Evaluasi Program Komunikasi (Evaluation Of Communication Programmes)

Sejumlah skema analitis telah dikembangkan untuk mengevaluasi efek dari program media digital (lihat Jeffries-Fox, 2004; Paine 2007a, 2007b; Phillips \& Young, 2009). Ini berkisar dari langkah-langkah sederhana hits pada situs untuk tindakan kognisi, sikap, dan perilaku, serta indikator dari jenis dan kualitas hubungan. Dalam banyak kasus, langkah-langkah ini dapat diterapkan secara langsung ke konten online. Dalam kasus lain, survei tambahan atau penelitian eksperimental akan diperlukan.

\section{Memahami Hubungan Media}

Secara teknis, ada beberapa hal yang harus dipahami oleh seorang PR terutama dalam membangun hubungan dengan media menurut Frank Jefkins adalah sebagai berikut :

1. Memahami media: yaitu dengan mengetahui karakteristik masing-masing media, kekuatan dan kelemahannya, bagaimana memproduksi berita, program di radio dan televisi. Caranya dengan pengamatan, melakukan kunjungan ke meddia, melakukan wawancara melalui telepon mengenai hal-hal yang 
terkait dengan upaya untuk lebih mengenali media.

2. Memahami hal penting tentang media sebagai berikut:

a. Kebijakan editorial,

b. frekuensi penerbitan,

c. tanggal terbit,

d. proses percetakan/produksi,

e. daerah sirkulasi/siaran,

f. jangkauan pembaca/pendengar/pem irsa,

g. metode distribusi untuk media cetak (langganan/eceran), metode kerjasama dengan radio/tlevisi dalam pembuatan program acara.

3. Memahami dan melaksanakan prinsip-prinsip hubungan baik yaitu:

a. memahami dan melayani media,

b. membangun reputasi sebagai orang yang bisa dipercaya,

c. menyediakan salinan naskah berita (press release), foto, rekaman suara (untuk radio), dan rekaman gamabr (untuk televisi),

d. bekerjasama dalam penyajian materi (wawancara, konferensi pers, program siaran langsung untuk radio, talkshow untuk televisi, dan lain-lain),

e. menyediakan fasilitas verifikasi atau pembuktian akan kebenaran materi yang mereka terima misalnya dengan kunjungan ke perusahaan (open house), kunjungan ke pabrik, lapangan, pusat-pusat industri/aktifitas organisasi lainnya,

f. membangun hubungan personal yang kokoh dan positif.

4. Memahami tanggung jawab dan loyalitas yang saling bertentangan antara praktisi humas yang mewakili kepentingan organisasi dan wartawan yang mewakili perusahaan/industri media. (Jefkins: 2000:hal.100-102).

Adapun jenis-jenis media relations adalah sebagai berikut

a. Press Conference (Konferensi Pers) mengundang wartawan untuk berdialog dengan materi yang telah disiapkan (Press Kit, Media Kit).

b. Press Briefing (Jumpa Pers) -penyampaian informasi dalam sebuah kegiatan.

c. Special Event -kegiatan khusus yang melibatkan media, misalnya menjadi sponsor lomba penulisan jurnalistik.

d. Media Visit (Kunjungan Media) -berkunjung ke kantor media.

e. Undangan Peliputan mengundang wartawan untuk meliput acara.

f. Press Gathering mengundang media untuk berkumpul secara informal, misalnya jamuan makan malam.

g. Press Luncheon -jamuan makan siang.

h. Maintenance Lobby misalnya minum kopi bersama, nonton bareng. 
i. Press Tour - mengajak wartawan berkunjung ke suatu tempat.

Hubungan dengan media membutuhkan pemahaman tentang media, meliputi hal-hal sebagai berikut:

a. Editorial Policy, yaitu kebijakan redaksional - kriteria berita/tulisan yang layak muat (fit to print) atau layak siar (fit to broadcast) berdasarkan visi, misi, dan rubrikasi media.

b. Frequency of Publication periode terbit, yaitu harian, mingguan, bulanan, dan sebagainya.

c. Copy Date atau Dead Libe batas waktu masuknya berita ke editor/redaksi.

d. Printing Process -proses percetakan atau penerbitan.

e. Circulations Area -cakupan wilayah sebaran media atau jangkauan pembaca/audiens.

f. Readership Profile -karakteristik pembaca, penonton, atau pendengar, dari segi kelompok umur, jenis kelamin, tingkat sosial, profesi, hobi dan minat, kebangsaan, kelompok etnis, agama, dan orientasi politik.

g. Distribution Method - cara penyebaran media, misalnya dijual eceran di toko buku, eceran langsung di terminal, rumah ke rumah, atau berlangganan. (Jefkins, 1991).

Sementara Cutip, Center dan Broom dalam bukunya Effective Public Relations (2006) membagi media komunikasi dalam tiga bentuk yaitu :

\section{The Printed Word}

Maksudnya adalah media berupa tulisan, atau media tertulis/tercetak, contoh beberapa media yang dapat dilaksanakan untuk kegiatan organisasi meliputi media

The Printed Word:

1. Organizational Publication, adalah penerbitan/publikasi organisasi, berupa :

a. majalah organisasi yang memuat berita-berita tentang kegiatan-kegiatan organisasi dan prestasi yang telah dicapai oleh anggota organisasi

b. Surat kabar organisasi (dalam bentuk tabloid), isinya bertujuan untuk mempromosikan organisasi dalam rangka untuk menciptakan/memperoleh citra baik dari publiknya.

2. Pamplets, Brosur, manual dan buku

3. Press Release dan Counter Release

4. Surat-surat

5. Insert dan Enclosures

6. Bulletin Boards, posters, billboards

7. Naskah pidato

8. Foto, grafik dan lukisan

\section{The Spoken Word}

Istilah yang digunakan dalam kegiatan organisasi untuk Media lisan, Ada dua klasifikasi the spoken word :

- Media Internal, meliputi :

○ Meeting

- Closed Circuit Television

- Teleconferencing

- Telephone

- Media Ekternal, ,meliputi :

- Press conference / konferensi pers

- Siaran radio

- Press interview

- Tape recorder

- Press tour 
Public Relations Dalam Membina Hubungan Dengan Media | 53

\section{The image}

Istilah image ini digunakan kedalam media audio visual, dimana media ini mempunyai kelebihan yang bisa memberikan kombinasi sebagai media pandang dan dengar. Yang termasuk kedalam media the image ini adalah :

- Televisi

- Film

- Slides Film

- Open House

- Cable Television

- Stage Event

- Internet

- Pameran dan demonstrasi

- Sticker

- Sponsor

\section{Lingkup Media dalam Media Relations}

Organisasi sering menyusun apa yang dikenal sebagai daftar media, atau daftar media yang mungkin diminati oleh informasi organisasi. Media bisa terdiri dari ribuan publikasi majalah, surat kabar, dan stasiun TV dan radio serta media online. Dalam kaitannya dengan hal ini, seorang praktisi PR wajib mengetahui citra media yang akan dijadikan kerjasama terutama dalam membentuk citra dan reputasi perusahaan, Dewan Pers telah membuat verifikasi media yang penting untuk diketahui oleh seorang praktisi PR, yang penulis kelompokkan sebagai berikut

\begin{tabular}{|l|l|l|}
\hline $\begin{array}{l}\text { Media } \\
\text { Cetak }\end{array}$ & $\begin{array}{l}\text { Media } \\
\text { elektronik }\end{array}$ & Media Online \\
\hline Analisa & ANTV & arah.com \\
\hline Bali Post & $\begin{array}{l}\text { Balikpapan } \\
\text { TV }\end{array}$ & cnnindonesia.com \\
\hline Balikpapan & Berita Satu & detik.com \\
Pos & News & \\
\hline
\end{tabular}

\begin{tabular}{|c|c|c|}
\hline & Channel & \\
\hline Berita Pagi & $\begin{array}{l}\text { Celebes } \\
\text { TV }\end{array}$ & kompas.com \\
\hline $\begin{array}{l}\text { Bisnis } \\
\text { Indonesia }\end{array}$ & CTV & metrotvnews.com \\
\hline $\begin{array}{cc}\text { Cek } & \& \\
\text { Ricek } & \end{array}$ & Elshinta & okezone.com \\
\hline Fajar & Global TV & rmol.co \\
\hline Femina & Indosiar & viva.co.id \\
\hline $\begin{array}{l}\text { 9. Globe } \\
\text { Asia }\end{array}$ & $\begin{array}{l}\cdot{ }^{\text {iNEWS }} \\
\text { TV }\end{array}$ & arah.com \\
\hline 10. Haluan & JTV & cnnindonesia.com \\
\hline $\begin{array}{l}\text { 11. Harian } \\
\text { Jogja }\end{array}$ & KBR & detik.com \\
\hline 12. Investor & Kompas TV & kompas.com \\
\hline $\begin{array}{l}\text { 13. Investor } \\
\text { Daily }\end{array}$ & $\begin{array}{l}\text { LKBN } \\
\text { ANTARA }\end{array}$ & metrotvnews.com \\
\hline $\begin{array}{l}\text { 14. Kaltim } \\
\text { Pos }\end{array}$ & Metro TV & okezone.com \\
\hline $\begin{array}{l}15 . \\
\text { Kedaulatan } \\
\text { Rakyat }\end{array}$ & MNC TV & rmol.co \\
\hline 16. Kompas & PR Radio & viva.co.id \\
\hline $\begin{array}{l}\text { 17. Koran } \\
\text { Sindo }\end{array}$ & $\begin{array}{l}\text { Pronews } \\
\text { FM }\end{array}$ & \\
\hline $\begin{array}{ll}\text { 18. } & \text { Koran } \\
\text { Solo } & \end{array}$ & $\begin{array}{l}\text { Radio } \\
\text { DMS }\end{array}$ & \\
\hline 19. Media & RCTI & \\
\hline
\end{tabular}

ISSN 2548-3749| Vol 3, No.1, Juni 2018 
54 Diajeng Herika, et al.

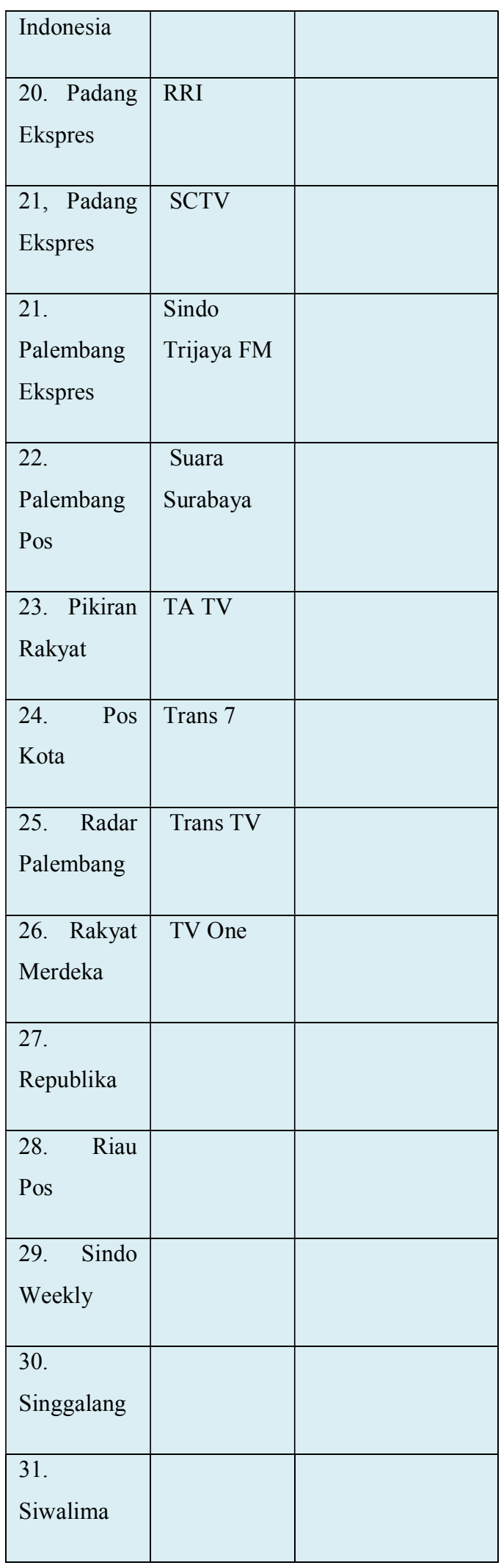

\begin{tabular}{|c|c|c|}
\hline $\begin{array}{ll}32 . & \text { Solo } \\
\text { Pos } & \end{array}$ & & \\
\hline $\begin{array}{l}33 . \\
\text { Sriwijaya } \\
\text { Post }\end{array}$ & & \\
\hline $\begin{array}{l}\text { 34. Suara } \\
\text { Merdeka }\end{array}$ & & \\
\hline $\begin{array}{l}\text { Suara } \\
\text { Pembaruan }\end{array}$ & & \\
\hline $\begin{array}{l}6 . \\
\text { Sumatera } \\
\text { Ekspres }\end{array}$ & & \\
\hline $\begin{array}{l}37 . \quad \text { The } \\
\text { Peak } \\
\text { Indonesia }\end{array}$ & & \\
\hline $\begin{array}{l}\text { 38. Tribun } \\
\text { Kaltim }\end{array}$ & & \\
\hline $\begin{array}{l}\text { 39. Tribun } \\
\text { Pekanbaru }\end{array}$ & & \\
\hline $\begin{array}{l}\text { 40. Tribun } \\
\text { Sumsel }\end{array}$ & & \\
\hline $\begin{array}{l}\text { 41. Tribun } \\
\text { Timur }\end{array}$ & & \\
\hline $\begin{array}{l}42 . \\
\text { Waspada }\end{array}$ & & \\
\hline
\end{tabular}

https://www.antaranews.com/berita/610

730/daftar-media-yang-sudah-

terverifikasi-oleh-dewan-pers

Salah satu alasan verifikasi media yang dilakukan oleh Dewan Pers 
menegaskan bahwa program verifikasi perusahaan pers yang mereka lakukan sebagai amanat Undang-Undang Nomor 40 Tahun 1999 tentang Pers, selain untuk mendata perusahaan pers sekaligus memastikan pelaksanaan komitmen mereka dalam menegakkan profesionalitas dan perlindungan terhadap wartawan, guna mewujudkan kemerdekaan pers. Kemudian dikemukakan pula oleh Ketua Dewan Pers, Yosep Adi Prasetyo bahwa "Pers dalam menjalankan perannya harus menjunjung kemerdekaan pers, menyampaikan informasi kepada publik secara jujur dan berimbang, serta bebas dari tekanan kapitalisme dan politik," Selain itu, lewat verifikasi perusahaan pers, Dewan Pers ingin mendorong penguatan media pers dan penempatan media-media arus utama dalam memasuki era konvergensi media, yang menjadi konsekuensi pesatnya perkembangan teknologi digital. Media arus utama harus bisa mengembalikan kepercayaan publik dengan menjawab tantangan atas maraknya serbuan hoax atau informasi bohong yang dibuat seolah-olah karya jurnalistik.

Pendataan perusahaan pers yang mengharuskan pengelola media menegakkan KEJ (Kode Etik Jurnalistik), kaidah jurnalistik sekaligus mensertifikasi, menyejahterakan dan melindungi wartawannya sebagai prasyarat, diyakini Dewan Pers sebagai langkah strategis ketika Indonesia sudah memasuki pasar bebas Masyarakat Ekonomi ASEAN (MEA), yang membuat persaingan tidak lagi meliputi pergerakan barang tetapi juga jasa profesional, termasuk wartawan.

Dalam

prakteknya

melaksanakan media relations bukanlah hal yang mudah, bahkan sering terdapat beberapa kasus perselisihan antara individu, organisasi/perusahaan dengan media yang terkait dengan publikasi. Perusahaan atau organisasi mengeluh mengenai isi pemberitaan media yang cenderung bersifat negatif. Kasus-kasus tersebut bisa saja terjadi mengingat adanya perbedaan tanggung jawab dan loyalitas antara praktisi Public Relations yang membawa nama organisasi/perusahaan dengan wartawan yang mewakili media massa

\section{Kesimpulan}

Berdasarkan uraian di atas, dapat disimpulkan bahwa peran public relatioms dalam membina hubungan media sangat penting dapat digambarkan sebagai interaksi perusahaan dengan editor, reporter dan jurnalis. Media bisa berupa surat kabar, radio, televisi dan internet. Tujuannya adalah untuk mengkomunikasikan pesan, cerita atau informasi yang layak diberitakan kepada klien menggunakan media yang sesuai.

Penggunaan empat model PR Grunig dan Hunt yang diaplikasikan dalam kegiatan PR dengan menggunakan media digital saat ini digunakan secara luas untuk program komunikasi yang satu arah dan asimetris. Namun, banyak organisasi sekarang sedang mengembangkan dua arah, interaktif, dan program komunikasi dialogis melalui media digital, terutama menggunakan blog dan mikroblog seperti Twitter.

Spesialis hubungan media biasanya terhubung dengan dunia media setiap hari. Para profesional ini bekerja untuk mengembangkan dan merancang rencana media yang bisa menjadi cetak biru untuk apa yang diharapkan perusahaan capai di tingkat lokal, nasional atau internasional. Strategi bisnis dirancang untuk mengelola dan menciptakan persepsi positif terhadap perusahaan.

Sebagai spesialis hubungan media yang efektif, sangat penting untuk bekerja sama dan tidak melawan media. Mengembangkan hubungan 
yang kuat dengan para jurnalis, blogger, dan penulis konten yang mungkin ingin mendengar apa yang harus Anda katakan, dapat memberi klien Anda akses tak ternilai kepada publik. Sementara garis tak terlihat ditarik antara hubungan masyarakat dan hubungan media, para profesional di kedua bidang harus menjadi ahli dalam komunikasi massa untuk menjadi sukses. Informasi tren harus diantisipasi dan dipahami dengan baik sebelumnya. Dan itu harus cepat diakses.. Dengan demikian, media ini memiliki potensi untuk benar-benar revolutionalise dalam kegiatan PR dan akan berubah terjadi pergeseran paradigma dalam pemikiran publik

\section{Daftar Pustaka}

Bardhan, N. R. (2003). Rupturing public relations metanarratives: The example of India. Journal of Public Relations Research, 15, 225-248.

Bromley, D. B. (1993). Reputation, image, and impression management. Chichester, UK: John Wiley \& Sons.

China Internet Network Information Center (2009, January). The 23rd statistical survey report on the internet development in China.

CNN.com (January 14, 2009). China tops world in internet users. Retrieved 1 November from http://www.cnn.com/2009/TECH/01 /14/china.internet/index.html.

Coombs, W. T. (2007, October 30). Crisis management and communication. Gainesville: FL: Institute for Public Relations Essential Knowledge Project. Retrieved 1 November 2007 from http://www.instituteforpr.org/essenti al_knowledge/detail/crisis_manage ment and communications/
Coombs, W. T. (2008, April 2). Crisis communication and social media. Gainesville: FL: Institute for Public Relations Essential Knowledge Project. Retrieved 1 November 2009 from

http://www.instituteforpr.org/essenti al knowledge/detail/crisis commun ication_and_social_media/

Dozier, D. M., \& Ehling, W. P. (1992). Evaluation of public relations programs: What the literature tells us about their effects. In J. E. Grunig (Ed.), Excellence in public relations and communication management (pp. 159-184). Hillsdale, NJ: Lawrence Erlbaum Associates.

Edelman and First\&42nd (2006). Corporate social responsibility and sustainability in the blogosphere: Who's participating in the conversation, and who isn't? New York: Edelman Public Relations.

Grunig, J. E. (1992). (Ed.) Excellence in public relations and communication management Hillsdale, NJ: Lawrence Erlbaum.

Grunig, J. E. (1993). Image and substance: From symbolic to behavioural relationships. Public Relations Review, 91(2), 121-139.

Grunig, J. E. (1997). A situational theory of publics: Conceptual history, recent challenges and new research. In D. Moss, T. MacManus, \& D. Vercic (Eds.), Public relations research: An international perspective (pp. 3-46). London: International Thomson Business Press.

Grunig, J. E. (2001). Two-way symmetrical public relations: Past, present, and future. In R. L. Heath (Ed.), Handbook of public relations (pp. 11-30). Thousand Oaks, CA: Sage. 
Grunig, J. E. (2002). Qualitative methods for assessing relationships between organizations and

Grunig, J. E., Grunig, L. A., Sriramesh, K., Huang, Y. H., \& Lyra, A. (1995). Models of public relations in an international setting. Journal of Public Relations Research 7, 163186.

Grunig, J. E., \& Huang, Y. H. (2000). From organizational effectiveness to relationship indicators: Antecedents of relationships, public relations strategies, and relationship outcomes. In J. A.

Ledingham \& S. D. Bruning (Eds.), Public relations as relationship management: A relational approach to the study and practice of public relations (pp. 23-53). Mahwah, NJ: Lawrence Erlbaum Associates.

Grunig, J. E. \& Hung, C. J. (2002, March). The effect of relationships on reputation and reputation on relationships: $A$ cognitive, behavioural study. Paper presented to the Public Relations Society of America Educator's Academy, Miami, Florida.

Grunig, L. A., Grunig, J. E., \& Dozier, D. M. (2002). Excellence in public relations and communication management: A study of communication management in three countries. Mahwah, NJ: Lawrence Erlbaum Associates.

Harris, R. (2009, October 16). Using social media to remain transparent: Crisis response, reputation, management and research. Presentation to the Summit on Measurement, Institute for Public Relations, Portsmouth, New Hampshire.

Hatch, M. J. (1997). Organization theory: Modern, symbolic, and postmodern perspectives. Oxford: Oxford University Press.
Holtzhausen, D. R., \& Voto, R. (2002). Resistance from the margins: The postmodern public relations practitioner as organizational activist. Journal of Public Relations Research, 14, 57-84.

Hon, L. C., \& Grunig, J. E. (1999). Guidelines for measuring relationships in public relations.

Gainesville, FL: The Institute for Public Relations, Commission on PR Measurement and Evaluation.

Hung, C. J. (2007). Toward the theory of relationship management in public relations: How to cultivate quality relationships. In E. L. Toth (Ed.), The future of excellence in public relations and communication management: Challenges for the next generation (pp.443-476). Mahwah, NJ: Lawrence Erlbaum Associates.

IABC Research Foundation \& Buck Consultants (2009). Employee engagement survey: Survey results. San Francisco: International Association of Business Communicators.

Internet World Stats: Usage and Population Statistics (2009). Internet usage statistics: The internet big picture: World internet users and population stats. Retrieved 1 November from http://www.internetworldstats.com/s tats.htm.

Jeffries-Fox, B. (2004). A primer in internet audience measurement. Gainesville, FL: Institute for Public Relations, Commission on Public Relations Measurement and Evaluation.

Kim, J. N. (2006). Communicant activeness, cognitive entrepreneurship, and a situational theory of problem solving. Unpublished doctoral dissertation, University of Maryland, College Park. 
Ruliana, Poppy, 2014. Komunikasi Organisasi, Teori dan Studi Kasus. Jakarta: Rajagrafindo

https://www.antaranews.com/berita/610

730/daftar-media-yang-sudahterverifikasi-oleh-dewan-pers 